\title{
IAMJ
}

INTERNATIONAL

AYURVEDIC

MEDICAL JOURNAL

\section{A COMPARATIVE STUDY BETWEEN THE SHARIRA STHANA OF ASHTANGA SANGRAHA AND ASHTANGA HRIDAYA}

\author{
$\underline{\text { Anitta Raipuria }}^{1}, \underline{\text { M.R. Saijan Shetty }}{ }^{2}$, G.N. Kannoli ${ }^{2,} \underline{\text { Varun Raipuria }}^{3}$ \\ ${ }^{1}$ Asst.Professor, Department of Samhita Siddhanta, Murlidhar Ayurveda Medical College, Rajkot, Gujarat, India. \\ ${ }^{2}$ Professor, ${ }^{2}$ Asst. Professor, Department of Samhita Siddhanta, SVM Ayurveda Medical College and P.G. \\ Research Centre, Ilkal, Karnataka, India. \\ ${ }^{3}$ Asst. Professor, Department of Agada Tantra, Murlidhar Ayurveda Medical College, Rajkot, Gujarat, India
}

Corresponding Author: anittajames777@gmail.com

https://doi.org/10.46607/iamj1909052021

(Published Online: May 2021)

Open Access

(C) International Ayurvedic Medical Journal, India 2021

Article Received: 24/04/2021 - Peer Reviewed: 05/05/2021 - Accepted for Publication: 06/05/2021

Check for updates

\section{ABSTRACT}

Background and Objectives: There are works which contain information on comparative study of Sutra Sthana of Ashtanga Sangraha and Ashtanga Hridaya but no specific work on comparative study between Sharira Sthana is done. This study is one such work which includes comparative study between concepts mentioned in Ashtanga Sangraha and Ashtanga Hridaya which will help to reveal the unique concepts of both treatise which is the most essential part of the research. Aim: To study Sharira Sthana of Ashtanga Sangraha and Ashtanga Hridaya for comparative and literary purpose. Objectives: To study the basic concepts of Sharira sthana of Ashtanga sangraha and Ashtanga hridaya in the sequence of their chapters and mentioned concepts related with Sharira. To determinate similarities and differences between concepts of Sharira sthana of Ashtanga sangraha and Ashtanga hridaya and to find out the base and reason for considering similarities and differences. To present a hypothesis after studying, understanding, comparing and discussing the facts which will resolve the hidden ancient knowledge of Samhita. Methods: Collecting in sequential order of each chapter the concepts mentioned in Sharira sthana of Ashtanga Sangraha and Ashtanga Hridaya. Comparing in depth to find out the mentioned and not mentioned concepts between them and assessment of the reasons for the not mentioned concepts. Result: Result will be drawn on the basis of 
comparison. Conclusion: On the basis of result and mainly discussion, finally, the essence of this dissertation is enlightened, and conclusion will be drawn.

Keywords: Sharira, Sharira Sthana, Concepts, Ashtanga Sangraha, Ashtanga Hridaya.

\section{INTRODUCTION}

A strong foundation is essential to build a house for its longevity. There are many concepts existing in this world. Only existence of these, does not give their knowledge but when a need develops to know about these things, process of research starts. In the same way, the curiosity to know more about something and to have entire knowledge of it depends upon the basic fundamental principles. The basics principles of Ayurveda are developed from Samhita and Siddhanta and validity of basic principles of Ayurveda has kept this immortal science existing till date. Samhita is defined as the medical knowledge acquired in the early age which was documented systematically and organized scientifically in the compendia of Ayurveda ${ }^{1}$. Looking at the amazing journey of Ayurveda, it can be observed that initially verbal knowledge was converted into literature form for convenience to common mass and was named as different Samhitas. Siddhanta is the conclusion which is established by Acharyas after carefully testing in several ways and which is proved with reasoning ${ }^{2}$.

The ancient texts in Ayurveda were not reliably comprehended for scientific studies. They were very elaborate and didn't have an orderly description of topics. It was Acharya Vagbhata, the author of Ashtanga Sangraha who undertook the difficult task of composing a literature work, which includes the essence of its eight branches in precise, concise and comprehensive form and named this text as Ashtanga Hridaya ${ }^{3}$. Sharira sthana of both the texts describes in detail Janma (birth) and Marana (death) of the body hence the name given Sharira. Without basic education of the Sharira, the physician cannot become successful in the field of treatment and also in maintaining healthy life. The purpose of explaining the same entity with some similarities, dissimilarities and with new concepts about it; develops the curiosity to search more about that entity. So, it is the duty of research scholars to find out the truth which is hidden in the ancient treaties. This article is based on such a Literary research which is selected with the prime consideration on concepts mentioned in Ashtanga Sangraha and Ashtanga Hridaya Sharira Sthana and detailed literary data was collected and compared so as to find out the deep seated concepts mentioned in them.

\section{METHODOLOGY}

The present study was a literary research and method was followed as per the study design. In the beginning all the references on concepts of Sharira was collected and compiled with main reference to Ashtanga Sangraha and Ashtanga Hridaya. Then review on the concepts was done as per the classical texts and authorized commentators like Sasilekha commentary for A.S. and Arunadatta commentary for A.H. After this, concepts mentioned and not mentioned and the reason for the same in the view of both texts was explained. Here relevant references were compiled from the above-mentioned classical texts and their commentaries and sorted under the following sections in order to generate the review so as to fulfill the aims. The concepts mentioned in Sharira Sthana of Ashtanga Sangraha and Ashtanga Hridaya was searched and collected in sequential order of each chapters. The concepts collected was compiled and compared in depth to find out the mentioned and not mentioned concepts between them and the reasons for the not mentioned concepts were assessed. Reinforcement of this topic was the opinions from learned and experienced lectures, readers and professors of the department. A deep review was taken especially of the commentaries of Ashtanga Sangraha by Indhu and Astanga Hridaya by Arunadatta for deep views of the concept.

Aim: To study Sharira Sthana of Ashtanga Sangraha and Ashtanga Hridaya for comparative and literary purpose. 


\section{Objectives of The Study}

- To study and understand the basic concepts of Sharira Sthana of Ashtanga Sangraha and Ashtanga Hridaya in the sequence of their chapters and mentioned concepts related with Sharira.

- To determinate mentioned and not mentioned concepts between Sharira Sthana of Ashtanga Sangraha and Ashtanga Hridaya and to find out the base and reason for it.

- To present a hypothesis after studying, understanding, comparing and discussing the facts which will resolve the hidden ancient knowledge of Samhita.

\section{HYPOTHESIS}

- $\quad \mathbf{H}_{0}$-Sharira sthana of Ashtanga Sangraha and Ashtanga Hridaya are same.

- $\quad \mathbf{H}_{1}$ - Sharira sthana of Ashtanga Sangraha has more concepts than Ashtanga Hridaya.

- $\mathbf{H}_{-2-}$ Sharira sthana of Ashtanga Hridaya has more concepts than Ashtanga Sangraha.

\section{CONCEPTUAL REVIEW}

Ayurveda the science of longevity is one of the biosciences of Sharira or human body which has mainly two basic aims. The first aim is to maintain the health of a healthy person and to treat a diseased person. Various Acharyas have explained the knowledge of Sharira on their own perspective. Sharira is considered as the combination of Pancha mahabhuta (five basic primordial elements) and Atma (Soul) ${ }^{4}$. The science that deals with the knowledge of how human body is built and performs activities is called as Shaarira. The Sthana (division) of the Samhitas (Ayurvedic treatise) that describes about Sharira is called as Sharira Sthana, which describe in detail about the birth and death of the body.

As per Garbhopanishad, the word 'शरीर' is derived from the 'श्री - 'धातु it's meaning 'to deteriorate' or change from time to time ${ }^{5}$. The adishtana (residual place) of Cetana (Atma) along with the Pancha mahabhuta and its vikaras is known as Sharira ${ }^{6}$. The combination of sukra and sonita along with atma, pancha mahabhuta and vikara in the uterus is known as Garbha and it develops into a sharira by the role of pancha mahabhuta ${ }^{7}$. Dosha, dhatu, mala are the three main roots of the body. When they are in balanced state, they provide health and when in imbalance produces diseases in the body. Amarakosha mentions almost fourteen synonyms for Sharira ${ }^{8}$. The science which deals with the knowledge of how the human body is built is known as Shaarira. It gives knowledge about Sharira. As this section describes in detail about the birth and death of the body, it is called as Sharira sthana ${ }^{9,10}$.

\section{COMPARATIVE STUDY OF THE CON- CEPTS $^{11,12}$}

In the comparative study between the Sharira Sthana of Ashtanga Sangraha and Ashtanga Hridaya in sequential order of the chapters and the tables of comparison made as in review of literature, we have gone through many important concepts related to Sharira starting from birth to the death of an individual. 


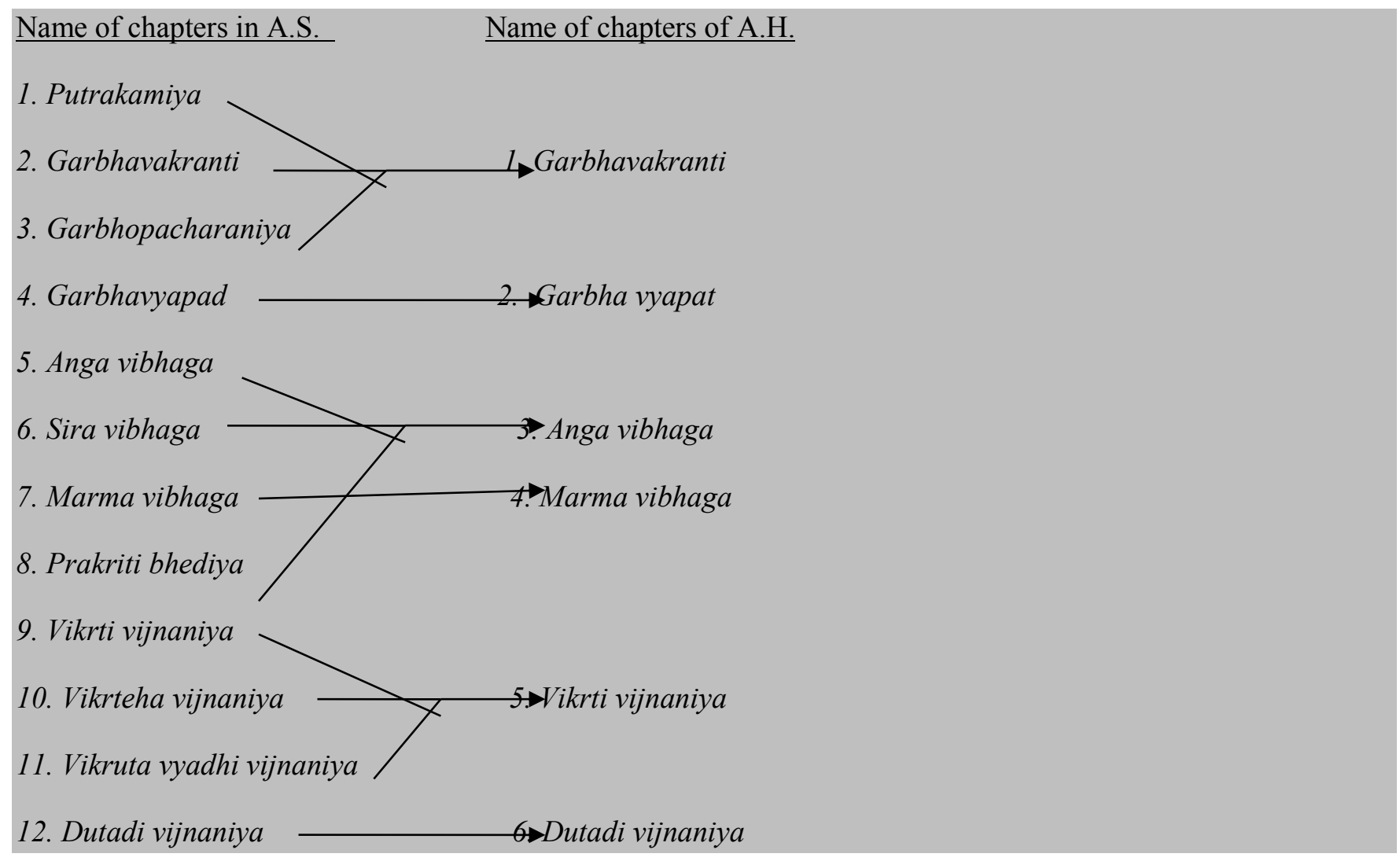

While comparing the concepts between the twelve chapters of A.S. and six chapters of A.H., the main feature found was that the concepts mentioned in the entire twelve chapters of A.S. was talent fully concise and briefed into six chapters in A.H. by Acharya Vagbhata. The first three chapters namely Putrakamiya, Garbhavakranti and Garbhopacharaniya was briefed into a single chapter named Garbhavakranti in A.H. The fourth chapter of A.S. named Garbha vyapat was the second chapter A.H. with the same name. The fifth, sixth and eighth chapters namely Anga Vibhaga, Sira Vibhaga and Prakriti Bhediya of A.S. was concised and briefed to a single chapter named Anga Vibhaga in A.H. The sixth chapter named Marma Vibhaga was the fourth chapter of A.H. with the same name. The ninth, tenth and eleventh chapters namely Vikrti Vijnaniya, Vikriteha Vijnaniya and Vikruta Vyadhi Vijnaniya of A.S. has been concised into one chapter named Vikrti Vijnaniya in A.H. The last chapter named Dutadi Vijnaniya was same in both.

On comparing the concepts in the first three chapters of A.S. and first chapter of A.H., out of the forty-two concepts compared, majority of the concepts around thirty were similar excluding some with minor changes in both the texts. Some concepts mentioned in A.S. were not mentioned in A.H. and vice versa. But A.H. has excluded many concepts that are mentioned in A.S. The main concepts in this section were 1.Garbha, 2.Karya karana Siddhanta in Garbha, 3. Garbha lingotpatti karana, 4.Vivahayogya stri, 5.Santhanayogya vaya, 6. Sukra, 7.Sukra lakshana, 8.artava, 9.its lakshana, 10.rakta gulma, 11.Garbha bhasa, 12.Dushta sukra artava \& 13.Cikitsa, 14.Ritukala, 15.Ritumati lakshana, 16.Ritumaticharya, 17.Maithuna kala, 18. Garbhadana karma, 19.Maithuna vidhi, 20.Sadhyo grahita garbha lakshana, 21.Pumsavana karma, 22. Garbhasthapana vidhi, 23.Garbha varna, 24.Satvaviseshakara bhava, 25.Vyakta garbha lakshana, 26. Garbha vrddhi lakshana 27. Garbha vrddhi krama, 28.Garbha poshana, 29.Vikrita garbha, 30.Vikrita garbhotpatti, 31.Garbhini rakshana, 32.Garbhopagatakara bhava, 33.Garbhinicarya, 34.Garbhini cikitsa, 35.Garbhini masopacara, 36.Sutikagara, 37.Asannaprasava lakshana, 38.Prasavopacara, 
39. Garbhasanga, 40.Aparapatana vidhi, 41.Makkalla, 42.Sutikopacara.

On comparing the concepts in Garbha vyapat chapter of both the texts, out of the eleven concepts mentioned, almost eight are similar and three concepts were not mentioned in A.H. The main concepts in this chapter were 1.Garbhasrava, 2.Garbhapata, 3.Upavishtaka, 4.Nagodara, 5.Linagarbha, 6.Udavarta, 7.Mritagarbha, 8.Mudagarbha, 9.Garbhasanga \& cikitsa, 10.Bala taila, 11.Masanumasika kashaya yoga in Garbhasrava.

On comparing the concepts in fifth, sixth and eighth chapters of A.S. and third chapter of A.H., the longest in the whole sthana, out of the fifty-eight concepts assessed, about forty three were similar and fifteen concepts were dissimilar. Among those, fourteen concepts were not mentioned well in A.H. and one in A.S. The main concepts in this chapter were 1.Anga pratyanga, 2.Panchabhautika sharira, 3.Matrja bhava, 4.Pitrja bhava, 5.Atmaja bhava, 6.Satmya bhava, 7.Rasaja bhava, 8.Satvadi bhava, 9.Sapta tvak, 10.Sapta kala, 11.Indriya \& Mana, 12.Sapta asaya, 13.Koshtanga, 14.Bandhana, 15.Dasa pranayatana, 16.Kandara, Jala, Pesi, 17.Asthi, 18.Asthi prakara, 19.Sandhi, 20.Sandhi prakara, 21.Snayu, 22.Sira dhamani mukhani, 23.Drava dhathu, 24.Anjali pramana, 25.Mula sira, 26.Mula dhamani, 27.dhamani prakara, 28. Sthula Srotas, 29.Sukshma Srotas, 30.Sroto mula, 31.Sroto dusti karana, 32.Sroto dusti lakshana, 33.Sroto vyadha lakshana, 34.Koshtagni \& bheda, 35.Ahara paka, 36.Bhutagni, 37.Dhatvagni, 38.Dhatu Parinama \& kala, 39.Dhatu mala, 40.Dhatu Parinama kala, 41.Koshtagni bheda, 42.Agni pradhanya, 43.Prakriti, 44.Prakriti Vikrti, 45.Para \& Rasa Ojus, 46.Vata, Pitta, Kapha Prakriti, 47.Samsargaja Prakriti, 48.Sama dosha Prakriti, 49.Manasa Prakriti, 50.Jatyadi Prakriti, 51.Trividha Vaya, 52.Trividha Bala, 53.Trividha Desa, 54.Dhatu pramana, 55.Ayu pramana, 56.Sara, 57.Sarira lakshana, 58.Sarira pramana.

On comparing the concepts in Marma chapter of both the texts, almost all concepts were similar in both the texts, except for the extra Dhamani marma mentioned in A.H. and also the difference in numbers in the types of Marmas mainly the Mamsa marma, Sira marma and Snayu marma. The main concepts in this chapter were 1.Marma Nama, Sthana, 2.Saakha marma, 3.Madhyamanga marma, 4.Jatrurdhva marma, 5.Marma Nirukti, 6.Mamsadi marma bheda, 7.Sadhyo Pranaharadi Marma Bheda, 8.Marma Viddha Lakshana, 9.Marma Pramana.

On comparing the concepts in ninth, tenth and eleventh chapters of A.S. and fifth chapter of A.H., out of the fifteen concepts assessed, ten concepts were similar and five were not mentioned in A.S. The main concepts in this chapter were 1.Rishta lakshana, 2.Rishta bheda, 3.Rishta bhasa, 4.Rishta bhava, 5.Rupa rishta, 6.Indriya rishta, 7.Svara rishta, 8.Varna, 9.Pratichaya \& nirukti, 10.Chaya rishta, 11.Pratichaya rishta, 12.Prabha, 13.Difference between Chaya \& Prabha, 14. Kriya rishta, 15.Vyadhi lakshana rishta.

On comparing the concepts in the last chapter of both the texts, out of the twelve concepts mentioned, ten were similar in both and two concepts were not mentioned in A.S. The main concepts in this chapter were 1.Duta lakshana, 2.Duta phala, 3.Asubha duta, 4.Subha duta, 5.Subha nimitta, 6.Paatha asubha nimitta, 7.Graha pravesa nimitta, 8.Asubha nimitta, 9.Svapna bheda \& phala, 10.Asubha svapna, 11.Asubha svapna karana, 12. Subha svapna.

\section{DISCUSSION}

Ancient Ayurvedic research methodology the Panchavayava Vakya is as strong as the modern research methodology. It is the duty of every individual research scholar to search out deeply about the concepts which is hidden in the ancient Ayurvedic literature. Any conclusion is of no use until it is strongly back supported by proper reasoning. Thus, present study was undertaken as the task to fill the lacunas of concepts by studying comparatively the concepts about Sharira sthana of Ashtanga Sangraha and Ashtanga Hridaya. All the data that were collected were rationally studied, compared and analyzed through discussion, so that an accurate conclusion can be reached.

The reference of Sharira has been available from Vedic time onwards. There were amble reference of Sharira in Atharvaveda and Krishna Yajurveda. Mentioning 
about theory of formation and development of human embryo was found from Garbhopanishad. Puranas like Markandeya Purana, Vishnu Purana and Shiva Purana also describes about Sharira and its types like Sthula sharira, Sukshma sharira and Karana Sharira. Looking into the Samhita period, Sharira has been mentioned well in the Sharira sthana of all Brihatrayee and Kasyapa Samhita too. Amarakosha book of seventh century described about Sharira paryaya. Bhava Prakasha in the Laghutrayee also has mentioned Sharira in its sixth chapter. References on Sharira were also available in the modern books. References on definition of Sharira Sthana were collected mainly from Ashtanga Sangraha and Ashtanga Hridaya.

That which change from time to time or which deteriorate is called as Sharira. Sharira is the abode where the Atma (soul) resides. It is by the combination of Sukra and Sonita along with Atma, Pancha Mahabhuta and Vikara in the uterus. It develops into a Sharira by the role of Pancha Mahabhuta. As birth and death of human body have been described in this section, it is called as Sharira Sthana.

Discussion on concepts mentioned in review of literature on chapters in Sharira Sthana of Ashtanga Sangraha and Ashtanga Hridaya

Ashtanga Sangraha Sharira sthana has 12 chapters namely (1) Putrakaamiya Adhyaya, (2) Garbhavakranti Adhyaya, (3) Garbhopacharaniya Adhyaya, (4) Garbhavyapad Adhyaya, (5) Anga vibhaga Sharira Adhyaya, (6) Sira vibhaga Adhyaya, (7) Marma vibhaga Adhyaya, (8) Prakritibhediya Sharira Adhyaya, (9) Vikrti Vijnaniya Adhyaya, (10) Vikriteha Vijnaniya Adhyaya, (11) Vikritavyadhi Vijnaniya Adhyaya and (12) Dutadi Vijnaniya Adhyaya.

Ashtanga Hridaya Sharira sthana has 6 chapters namely (1) Garbhavakranti Adhyaya, Garbhavyapad Adhyaya, (3) Anga vibhaga Adhyaya, (4) Marma vibhaga Sharira Adhyaya, (5) Vikrti Vijnaniya Adhyaya and (6) Dhutaadi Vijnaniya Adhyaya.

\section{Discussion on comparative study of concepts}

While comparing the concepts between the twelve chapters of A.S. and six chapters of A.H., the main feature found was that the concepts mentioned in the entire twelve chapters of A.S. was talent fully concised and briefed into six chapters in A.H. by Acharya Vagbhata. Discussion on first three chapters of A.S. with first chapter of A.H.

As said in the above passage, when comparing the concepts, it was found that the concepts mentioned in the first three chapters of A.S. was concised into a single chapter in A.H. Out of the forty two concepts compared almost thirty were similar in both of them and dissimilarities in concepts were more in A.H. as it has either not mentioned the concept or clubbed it with other concepts. The main contents of these chapters are the pre procedures before conception, just after conception, during pregnancy and after delivery so as to get best and healthy issue. Pumsavana karma the procedure to beget the desired child and which helps in Garbha Dharana and Sthereekarana is one of the important concepts described in this section. The concept of Pumsavana karma in a planned pregnancy has to be propagated wisely so as to reduce the problems of repeated abortions and infertility and to provide intelligent, healthy issue with good immunity, vigor and longevity.

Discussion on fourth chapter of A.S. with second chapter of A.H.

This chapter in both the texts deals with abnormalities during pregnancy. The concepts in both chapters are almost similar. But in a whole when we compare, again A.H. has omitted some points that has been mentioned in A.S. which he felt was not so important to mention. Repeated abortions, miscarriage etc are very common in the present scenario. Thus, the knowledge of these abnormalities is very essential for a physician so as to prevent such situations and also to treat such situations cleverly if it happens to a patient.

Discussion on fifth, sixth and eighth chapters of A.S. with third chapter of A.H.

When comparing the concepts, it was found that the concepts mentioned in the fifth, sixth and eighth chapters of A.S. was concised into a single chapter in A.H. and deals with the anatomical and physiological aspects of the body. In the comparison between these chapters also it was found that some concepts mentioned in A.S. 
was omitted, or not mentioned, or clubbed under other concepts in A.H.

\section{Discussion on seventh chapter of A.S. with fourth chapter of A.H.}

This chapter is about Marma, the untouched chapters of Indian surgery. With the exploration of these chapters deeply, the whole scenario of Indian medicine may change in both medical and surgical lesions. The concepts mentioned are similar in both the texts. But, A.H. was the first to classify Dhamani Marma. Nine marmas comes under this group namely Guda (1), Apasthambha(2), Vidhura(2) and Sringataka(4). As per A.S., Guda is mamsa marma, Vidhura is Snayu marma and Sringataka are Sira marma. Any injury to these Marmas will cause profuse bleeding in which froathy warm blood flows out with a sound and then the person easily loses consciousness and can lead to sudden or delayed death. Thus, considering the factor of injury to these vital spots and due to the presence of blood vessels in them, the chances of death are high. Therefore Dhamani marma as a separate category was introduced in A.H. this shows the practical approach of Acharya Vagbhata who was ready to propose new entities on his own practical observations.

Discussion on ninth, tenth and eleventh chapter of A.S. with fifth chapter of A.H.

When comparing the concepts, it was found that the concepts mentioned in the ninth, tenth and eleventh chapters of A.S. was concised into a single chapter in A.H. and deals with Arishta lakshana which are fatal signs and symptoms of death in a patient. Death does not occur without the appearance of fatal signs and life is impossible after it manifest. Such signs are expressed through different bodily elements like Varna, rupa, svara, indriya etc, by actions of the body called as Kriya/Ihayah rishta and also by the fatal signs in diseases. For a physician to know these fatal signs are very important as a physician who undertakes the treatment of incurable disease without the knowledge of them will surely lose his knowledge, success and wealth. While comparison, it was found that in this conceptual; section on fatal signs, the concepts of A.H. had more weightage than A.S. which again shows the practical approach of the author to propose new entities to his work.

\section{Discussion on twelfth chapter of A.S. with sixth chapter of A.H.}

Last chapter of both the texts deals with the same concept mainly knowledge of the signs and symptoms of auspicious and inauspicious messenger, auspicious and inauspicious omens and auspicious and inauspicious dreams. Knowledge of all these factors is very essential for a physician so as to avoid patients with such signs and symptoms as death is sure to occur in them.

\section{CONCLUSION}

Literary research is the backbone of any type of research. It enlightens the available resources and verifies the validity of the claims of previous research. Acharya Susruta says that the person, who studies only one science, will not be able to arrive at a correct decision; hence the physician should have knowledge of many sciences. This quotation explains us the need for compiling and comparing the concepts scattered in different texts so as to reveal the hidden concepts._Acharya Caraka says that the excellence in knowledge for a physician can be had by attending on preceptors and studying scriptures. Only then he will have a free hand in prescribing medicines. Thus, it is mandatory for a physician to have deep knowledge on the concepts mentioned in the texts. Only then he can use it practically. Sharira Sthana of A.S. contains 12 chapters and 565 shlokas and A.H. has 6 chapters and 558 shlokas. Thus, we can say that A.H. is the briefed version of A.S. itself compiled by including all the cardinal features mentioned in A.S. and other main treatises. While comparing the concepts in the Sharira Sthana of first eight chapters excluding marma chapter of A.S. and first three chapters of A.H., Concepts mentioned in Sharira Sthana of A.S. has more concepts than A.H. The descriptions on concepts like suitable age for marriage, Nourishment of foetus, Sroto mula, Sarira pramana, exact number of openings of blood vessels in the body, description on indriya, mana, ojus, prakriti vikriti etc are the special contributions by A.S. only.

While comparing the last four chapters of A.S. and last two chapters of A.H. which is on fatal signs of death, it 
looks like the descriptions of concepts in both are similar but the concepts in A.H. are more clearer and accurate which means Acharya has adopted the ideas of other authors too before writing this section so as to fill up the lacunas in the previous version and also to update the facts to the maximum possible ways. Whereas while comparing the commentaries of the texts, the writing and explaining style used by Acharya Arunadatta is best. Author's style in explaining some concepts are supreme. The maxims like Eka kala dhatu poshana nyaya, Pratisroto nyaya, Vrihinatapasoshayati nyaya, Dhamani marma vyakya etc are inevitable. The knowledge of Sharira is very essential and important in the field of life science. Without basic education of the Sharira, the physician cannot become successful in the field of treatment and also in maintaining healthy life. Thus, Sharira Sthana of the most updated version of Ayurvedic treatise were selected and studied to understand more deeply the hidden concepts mentioned in them. In a whole, after the study the main conclusion drawn is that the concepts in A.S. are more than that of A.H. Special contribution done by A.H. on the chapters on Arishta, Dutadi Vijnaniya and Dhamani Marma also should be taken into consideration.

\section{REFERENCES}

1. Monier Williams, A Sanskrit English Dictionary, New Delhi, Sri Sat guru Publications, 1993, Pg. no 1123

2. Agnivesa, Caraka Samhita, Ayurveda Dipika Commentary of Cakrapanidatta, Varanasi, Chaukhamba Prakashan, 2013, Pg. no 268

3. Vagbhata, Astanga Hridaya, Sarvanga Sundara of Arunadatta and Ayurveda Rasayana of Hemadri, Varanasi, Chaukhamba Sanskrit Sansthan, 2012, Pg.no 5

4. Agnivesa, Caraka Samhita, Ayurveda Dipika Commentary of Cakrapanidatta, Varanasi, Chaukhamba Prakashan, 2013, Pg. no 337

5. Raja Radha Kanta Deva, Sabda Kalpa Druma, Varanasi, Chowkhamba Sanskrit Series Office, Vol V, 2011, Pg. no 30

6. Agnivesa, Caraka Samhita, Ayurveda Dipika Commentary of Cakrapanidatta, Varanasi, Chaukhamba Prakashan, 2013, Pg. no 337
7. Susruta, Susruta Samhita, Nibandha sangraha Commentary of Dalhanacharya, Varanasi, Chaukambha Publications, 2012, Pg. no 363

8. Raja Radha Kanta Deva, Sabda Kalpa Druma, Varanasi, Chowkhamba Sanskrit Series Office, Vol V, 2011, Pg. no 30

9. Vagbhata, Astanga Sangraha, Sasilekha commentary by Indu, Varanasi, Chaukhamba Sanskrit Series, 2016, Pg.no-350

10. Vagbhata, Astanga Hridaya, Sarvanga Sundara of Arunadatta and Ayurveda Rasayana of Hemadri, Varanasi, Chaukhamba Sanskrit Sansthan, 2012, Pg.no 437

11. Vagbhata, Astanga Sangraha, Sasilekha Commentary by Indu, Varanasi, Chaukhamba Sanskrit Series, 2016, Pg.no-265-350

12. Vagbhata, Astanga Hridaya, Sarvanga Sundara of Arunadatta and Ayurveda Rasayana of Hemadri, Varanasi,Chaukhamba Sanskrit Sansthan, 2012, Pg.no $361-437$

\section{Source of Support: Nil \\ Conflict of Interest: None Declared}

How to cite this URL: Anitta Rajpuria et al: A Comparative Study Between The Sharira Sthana Of Ashtanga Sangraha And Ashtanga Hridaya. International Ayurvedic Medical Journal \{online\} 2021 \{cited May, 2021\} Available from: http://www.iamj.in/posts/images/upload/1059 1066.pdf 